\title{
THEORY OF PLANNED BEHAVIOR ON FACTORS AFFECTING EXCLUSIVE BREASTFEEDING: A PATH ANALYSIS EVIDENCE FROM SURABAYA
}

\author{
Zummatul Atika'), Harsono Salimo²), Yulia Lanti Retno Dewi3) \\ ${ }^{1)}$ Masters Program in Public Health, Universitas Sebelas Maret \\ ${ }^{2)}$ Department of Pediatrics, Dr. Moewardi, Surakarta \\ 3)Faculty of Medicine, Universitas Sebelas Maret
}

\begin{abstract}
Background: Infant and young child feeding is critical for child health and survival. Exclusive breastfeeding is the process of feeding a newborn baby exclusively with breast milk and no other supplement. It is recommended by WHO since it has several advantages for both child and mother. However, the prevalence of exclusive breastfeeding among infants younger than six months in developing countries remained low at 33\% in 1995 and 39\% in 2010. This study aimed to determine factors affecting exclusive breastfeeding using Theory of Planned and Behavior.
\end{abstract}

Subjects and Method: This was a cross sectional study carried out at 25 Posyandus (integrated family health posts) in Gunung Anyar Puskesmas (Community Health Center), Surabaya, East Java, Indonesia, from April to May 2018. A sample of 200 was selected from 25 Posyandus of 2 strata. The dependent variable was exclusive breastfeeding. The independent variables were intention, attitude, subjective norm, knowledge, family support, and health personnel support. The data were collected by questionnaire and analyzed by a path analysis. Results: Exclusive breastfeeding was directly affected by intention $(b=2.59 ; 95 \%$ $\mathrm{CI}=1.88$ to $3.30 ; \mathrm{p}<0.001)$ and attitude $(\mathrm{b}=1.19 ; 95 \% \mathrm{CI}=0.49$ to $1.90 ; \mathrm{p}=0.001)$. Exclusive breastfeeding was indirectly affected by subjective norm, knowledge, family support, and health personnel support.

Conclusion: Exclusive breastfeeding is directly affected by intention and attitude, but indirectly affected by subjective norm, knowledge, family support, and health personnel support

Keywords: exclusive breastfeeding, intention, attitude, subjective norm, knowledge, family support, health personnel support

\section{Correspondence:}

Zummatul Atika. Masters Program in Public Health, Universitas Sebelas Maret, Jl. Ir. Sutami No. 36 A, Surakarta, Central Java. Email: atikaprayogi6@gmail.com. Mobile: +6289656280307 . 